\title{
Etiology of Arthritis in Lomé (Togo)
}

\author{
Owonayo Oniankitan, Prénam Houzou, Komi C. Tagbor, Eryam Fianyo, Viwalé E. S. Koffi-Tessio, \\ Kodjo Kakpovi, Moustafa Mijiyawa
}

Department of Rheumatology, CHU Sylvanus Olympio, Lomé, Togo.

Email: Owonayo@yahoo.com

Received May $27^{\text {th }}, 2013$; revised June $28^{\text {th }}, 2013$; accepted July $6^{\text {th }}, 2013$

Copyright (C) 2013 Owonayo Oniankitan et al. This is an open access article distributed under the Creative Commons Attribution License, which permits unrestricted use, distribution, and reproduction in any medium, provided the original work is properly cited.

\begin{abstract}
Aim: Determine the frequency and respective proportion of the various etiological forms of arthritis in Lomé (Togo). Patients and Methods: Transversal study carried out over 15 years on files of arthritis infected patients and submitted to rheumatologic consultation. Results: 1081 out of 13,517 patients examined (8\%) were suffering from arthritis. Those 1081 patients (456 women, $42.2 \%$ and 625 men, $57.8 \%$ ) were in average 38 years old and enjoyed an average duration of evolution of three years. The chronic inflammatory rheumatisms (CIR) (602 cases, 56.9\%), the metabolic arthropathies (233 cases, 22\%) and the infections (198 cases, 16.6\%), were the main etiologies that were observed. The average age of 198 patients with infectious arthritis was 36 years and the average duration of 9 months. Infectious arthritis was preferably located at the knee (34.3\%), and was essentially caused by a banal germ (157 patients; $79.3 \%)$ and associated with HIV in 25 patients (15.9\%). The remaining 233 patients ( 9 women, and 224 men) suffering from metabolic arthritis were in average 52 years old and enjoyed an average duration of evolution of five years. The chronic inflammatory rheumatisms were mainly represented by spondyloarthropathies ( 90 cases, $14.9 \%$ ) and the arthritis rheumatoid (64 cases, 10.6\%). 399 out of 602 cases of the CIR were not classified while 52 cases were associated with HIV. The connective tissue diseases were dominated by the polymyositis (9 cases, 18.7\%). Conclusion: The chronic inflammatory rheumatisms were the first causal form of arthritis in rheumatologic consultation in Lomé.
\end{abstract}

Keywords: Black Africa; Arthritis; Etiology of Arthritis

\section{Introduction}

Arthritis is a common reason for consultation in rheumatology [1-3]. In the Sub-Saharan Africa, little epidemiological research has been devoted to arthritis $[2,4,5]$. The infectious disease is still common in sub-Saharan Africa because of the underdevelopment and poor hygiene. The reputation of the extreme rarity of gout in subSaharan Africa was contradicted by the work undertaken over the last 30 years [6]. The Spondyloarthropathies (SPA), in particular ankylosing spondylitis is rare in Africa and the link between HIV and the SPA in this region seems now well known [7]. Rheumatoid arthritis (RA) is frequent in Eastern and Southern Africa while in West and Central Africa it seems rare [8]. Systemic lupus erythematosus (SLE) is deemed rare in black Africa unlike scleroderma which seems frequent [8]. The studies conducted in hospitals focused on relatively small samples $[4,5,9,10]$. The aim assigned to this study was to determine in a large population suffering from rheumatism, the respective proportion of the different etiological forms of arthritis during a rheumatologic consultation in Lomé (Togo).

\section{Patients and Methods}

It has been a transversal study conducted from October 1989 to December 2005 of which the subject matter was to focus on the files of the patients suffering from arthritis and seen in clinical consultation of rheumatology. This springs from the study of a series of case records of patients admitted in the Department of Rheumatology, University Hospital Sylvanus Olympio, of Lomé, Togo's capital. The patients suffering from congestive osteoarthritis were not part of the sample study. The demographic (sex, age of the patient at diagnosis), clinical (arthritis characteristics, systemic manifestations associated), and paraclinical (radiographic, biologic, immunologic) data of patients were collected from their records. The patients suffering from gout perfectly answered to the criteria of ARA [11]. The spondyloarthropathies answered the criteria of Amor [12] and the rheumatoid arthritis pa- 
tients on their side answered to the criteria of ACR [13]. The connective tissue diseases on their part answered to the various diagnostic criteria. The positive diagnosis of the infectious arthritis has essentially been radio-clinical. The infection has been considered as certain in case of isolation of the causal germ in the organism or due to the underlining of evocative historical lesions in the suspected site. Otherwise, it was probable. Each patient has been the subject of a radiographic test of the infected part, of a hemogram, of a measurement of the speed of sedimentation, creatinine, and of a retroactive serology. A plasma creatinine greater than $115 \mu \mathrm{mol} / \mathrm{L}$ was considered as evidence of renal failure. The overweight has been defined as a corporal mass index (CMI) higher than $25 \mathrm{~kg} / \mathrm{m}^{2}$ while obesity is defined as a CMI higher than $30 \mathrm{~kg} / \mathrm{m}^{2}$. The immunologic tests undertaken had not been systematically conducted because of economic and technical limitations.

\section{Results}

\subsection{General Characteristics of the Patients}

One thousand and eighty one of the 13.517 patients examined (8\%) were suffering from arthritis. Those 1081 patients (made up of 456 women, $42.2 \%$; and 625 men, $57.8 \%$ ) were about 38 years old at the beginning of the disease and enjoyed an average duration of evolution of three years. The chronic inflammatory rheumatism (602 cases, 55.7\%) and the metabolic arthropathies (233 cases, $21.6 \%$ ), were the main etiologies of arthritis observed in Lomé (Table 1).

\subsection{Chronic Inflammatory Rheumatisms (CIR)}

The average age of the patients suffering from chronic inflammatory rheumatisms was 34.6 year old while the average duration of evolution is 2.2 year. The chronic inflammatory rheumatisms were essentially represented by: the spondyloarthropathies (90 cases, 14.9\%), the rheumatoid arthritis (64 cases, 10.6\%), and the juvenile chronic arthritis (10 cases, $1.66 \%$ ) (Table 2). Out of the 602 cases of CIR 399 cases were not classified. The 399 cases of CIR Unclassified fell into 295 cases $(73.9 \%)$

Table 1. Distribution of arthritis according to different clinical forms of arthritis.

\begin{tabular}{lcc}
\hline & Number of cases & Percentage \\
\hline Chronic inflammatory rheumatisms & 602 & 55.7 \\
Metabolic arthropathies & 233 & 21.6 \\
Arthritis infectious & 198 & 18.3 \\
Connective tissue diseases & 48 & 4.4 \\
Total & 1081 & 100 \\
\hline
\end{tabular}

Table 2. Demographic data of the patients infected with inflammatory rheumatisms and the connective tissue diseases according to the diagnosis.

\begin{tabular}{|c|c|c|c|}
\hline & $\begin{array}{c}\text { Number } \\
(\%)\end{array}$ & $\begin{array}{c}\text { Sex } \\
\text { W/M }\end{array}$ & $\begin{array}{l}\text { Age (years) } \\
\mathrm{m}^{ \pm} \mathrm{ET}^{* *}\end{array}$ \\
\hline Unclassified CIR ${ }^{* * *}$ & $399(63.7)$ & $226 / 173$ & $36.9 \pm 14.5$ \\
\hline Rheumatoid arthritis & $62(9.9)$ & $52 / 10$ & $41.8 \pm 18.2$ \\
\hline $\begin{array}{l}\text { Unclassified } \\
\text { spondyloarthropathies }\end{array}$ & $53(8.5)$ & $7 / 46$ & $34.4 \pm 10.1$ \\
\hline $\begin{array}{l}\text { Unclassified } \\
\text { connective tissue }\end{array}$ & $26(4.2)$ & $23 / 03$ & $34.9 \pm 15.3$ \\
\hline Ankylosing spondylitis & $22(3.5)$ & $0 / 22$ & $32.5 \pm 7.6$ \\
\hline Reactional arthritis & $17(2.7)$ & 08/09 & $34.7 \pm 10.2$ \\
\hline Polymyositis & $09(1.4)$ & $07 / 02$ & $39.4 \pm 09.5$ \\
\hline Chronic juvenil arthritis & $07(1.1)$ & $02 / 05$ & $08.8 \pm 04.9$ \\
\hline $\operatorname{SLE}^{* * * *}$ & $07(1,1)$ & $07 / 00$ & $42.6 \pm 08.2$ \\
\hline Scleroderma & $06(0.9)$ & $04 / 02$ & $40.8 \pm 13.5$ \\
\hline Horton disease & $05(0,8)$ & $04 / 01$ & $63.5 \pm 20.1$ \\
\hline Dermatomyositis & $04(0.6)$ & $02 / 02$ & $35.3 \pm 12.7$ \\
\hline Still disease & $03(0,5)$ & $02 / 01$ & $29.0 \pm 18.7$ \\
\hline Unclassified vascularitis & $03(0.5)$ & $01 / 02$ & $39.0 \pm 32.5$ \\
\hline Rheumatic fever & $02(0.3)$ & $01 / 01$ & $18.0 \pm 14.1$ \\
\hline Psoriasic rheumatism & $01(0.1)$ & $00 / 01$ & $45.0 \pm 00.0$ \\
\hline Total & $626(100)$ & $346 / 280$ & $36.9 \pm 14.9$ \\
\hline
\end{tabular}

${ }^{*}$ Women/Men, ${ }^{* *}$ average \pm standard deviation, ${ }^{* * *}$ unclassified chronic inflammatory rheumatisms, ${ }^{* * * *}$ Systemic lupus erythematosus.

of chronic polyarthritis, 80 cases $(20.1 \%)$ of isolated oligoarthritis and 24 cases $(6 \%)$ of isolated mono-arthritis. These 295 patients with chronic polyarthritis had an average age of 37.2 years and the average duration of the disease was 3 years. The chronic polyarthritis were characterized by the absence of deformation, joint destruction and systemic manifestations. The isolated oligoarthritis was sensitive to anti-inflammatory non-steroidal and had no radiological destruction. The 62 patients with rheumatoid arthritis had an age between 27 and 70 years. The average duration of evolution ranged from 3 months to 23 years. A distal joints location was observed in all patients (Table 3). The most frequent clinical forms of spondyloarthropathies were the ankylosing spondylitis (22 cases) and the reactional arthritis (17 cases). The chronic inflammatory rheumatisms were associated with HIV in 52 patients (spondyloarthropathies: 22 cases of which 17 cases of reactional arthritis, not classified inflammatory rheumatisms: 22 cases and rheumatoid arthritis: two cases).

The connective tissue diseases were dominated by the polymyositis ( 9 cases, 18.7\%), the systemic lupus erythematosus ( 7 cases, 14.6\%), and the scleroderma (6 cases, 
Table 3. Clinical and paraclinical manifestations observed in 62 patients with rheumatoid arthritis.

\begin{tabular}{|c|c|c|}
\hline & Number & Percentage \\
\hline Distal joint location & 62 & 100 \\
\hline Coxitis & 4 & 6.5 \\
\hline Cervical spine affected & 5 & 8.1 \\
\hline $\begin{array}{l}\text { Erythrocyte sedimentation rate } \geq 20 \mathrm{~mm} \\
\text { (ranged from } 25 \text { to } 131 \mathrm{~mm} \text { in the first hour) }\end{array}$ & 62 & 100 \\
\hline $\begin{array}{l}\text { Present of a rheumatoid factor in } 40 \\
\text { patients explored }\end{array}$ & 25 & 40.3 \\
\hline Present of bilateral carpitis & 43 & 69.3 \\
\hline $\begin{array}{l}\text { Present of a demineralization in band } \\
\text { of the hands and wrists }\end{array}$ & 19 & 30.6 \\
\hline
\end{tabular}

$12.5 \%)$. The symptomatology of 13 patients with polymyositis-dermatomyositis was dominated by muscle weakness (13 cases), myalgia (10 cases), arthralgia and swelling of the face ( 8 cases). The erythrocyte sedimentation rate was between 40 and $121 \mathrm{~mm}$ in the first hour. Creatinine phosphokinase was increased in 10 patients explored with a value between 1300 and $4500 \mathrm{IU} / \mathrm{L}$ (normal range 15 - $110 \mathrm{IU} / \mathrm{L}$ ). The most frequent clinical manifestations of systemic lupus erythematosus were alteration of general condition (five cases), polyarthralgia (seven cases), discoid lupus (six cases), malar rash (four cases), alopecia (three cases), and seritis (three cases). Laboratory findings included haemolytic anemia (five cases), and leucocytopenia (three cases), Antinuclear and anti-DNA antibodies were detected in three patients explored.

\subsection{Metabolic Arthritis}

Among the 233 patients ( 9 women and 224 men) with metabolic arthritis, 229 were suffering from gout $(98.3 \%)$ and the four others suffered from chondrocalcinosis $(1.7 \%)$. The average age of the patients suffering from metabolic arthritis was 52 years old and the average duration of evolution five years. The average age of the 229 patients (six women, 223 men) suffering from gout was 52 years. The average duration of evolution of gout upon diagnostic was five years. Fifty patients (21.8\%) had tophus; one patient had a nephritic colic. No risk factor has been found with eight patients $(3.5 \%)$. Each of the 221 other patients $(96.5 \%)$ had at least one risk factor (Table 4).

\subsection{Arthritis Infectious}

The 198 patients (100 women and 98 men) suffering from infectious arthritis had an average age of $36.26 \pm$ 17.47 years and an average duration of evolution of 9.28 \pm 9.84 months. The knee $(34.3 \%)$ was the most affected joint. The reach was essentially mono-articular (159 pa- tients: $80.3 \%)$. Clinical signs were associated with a joint stiffness (180 patients, 90.9\%) together with local inflammatory signs (97 patients, 49\%) (Table 5). The infectious gate was essentially cutaneous (30 patients, $15.2 \%$ ), uro-genital (23 patients, $11.6 \%$ ), and pleuropulmonary (18 patients, $9.1 \%$ ). The arthritis was caused by a banal germ in 157 cases ( 34 certain cases, and 123 probable cases) and by bacillus of Koch in 41 other cases (10 confirmed cases and 31 probable cases). The causal germ of the infection has been isolated in 39 of the 198 patients (19.7\%). The staphylococcus aureus has been for most of the time the cause (42.5\%). Apart from the weak economic level and the insufficiency of hygiene that has been observed in 172 patients $(86.9 \%)$, the other risk factors that have been identified were the HIV infection source (28 cases), alcoholism (10 cases), Sickle-cell anemia (eight cases), a malignant tumor (three cases), and the diabetes (two cases).

Table 4. Risk factors for gout and co-morbid conditions in 229 patients with gout.

\begin{tabular}{lcc}
\hline & Number of patients & Percentage \\
\hline Alcoholism & 193 & 84.3 \\
Overweight/obesity & 96 & 41.9 \\
Arterial high blood pressure & 65 & 28.4 \\
Family history of gout & 27 & 11.8 \\
Renal failure & 21 & 9.2 \\
Hypertriglyceridemia & 18 & 7.9 \\
Hypercholesterolemia & 12 & 5.2 \\
Diabetes mellitus & 5 & 2.3 \\
\hline
\end{tabular}

Table 5. Clinical and paraclinical manifestations observed in 198 patients with infectious arthritis.

\begin{tabular}{lcc}
\hline & $\begin{array}{c}\text { Banal germ arthritis } \\
(157 \text { cases }) \\
\text { Number }(\%)\end{array}$ & $\begin{array}{c}\text { Tuberculous arthritis } \\
\text { Number }(\%)\end{array}$ \\
\hline $\begin{array}{l}\text { Inflammatory pain } \\
\text { Monoarticular infectious }\end{array}$ & $157(100)$ & $18(43.9)$ \\
Olygoarticular infectious & $34(21.6)$ & $38(92.7)$ \\
$\begin{array}{l}\text { Joint stiffness } \\
\text { High fever }\end{array}$ & $157(100)$ & $3(7.3)$ \\
$\begin{array}{l}\text { Leucocytosis } \\
\begin{array}{l}\text { Erythrocyte sedimentation } \\
\text { rate } \geq 20 \text { mm }\end{array}\end{array}$ & $149(50.3)$ & $23(56.1)$ \\
$\begin{array}{l}\text { Infectious arthritis } \\
\text { associated with HIV }\end{array}$ & $106(67.5)$ & $11(26.8)$ \\
$\begin{array}{l}\text { Radiological signs } \\
\text { of joint infection }\end{array}$ & $118(75.1)$ & $35(85.4)$ \\
\hline
\end{tabular}




\section{Discussion}

This study shows the crucial importance of arthritis in rheumatologic consultation in Lomé. Arthritis has, for 15 years, motivated the study of the consultation of $8 \%$ of the patients suffering from rheumatism. Despite the fact that there are insufficiencies (hospital recruiting, narrowness of the technical scale), this study, like those conducted in other countries, testifies the importance of the CIR in spite of the weight of the infectious pathology in Africa [11,12]. The importance of the CIR is the reflection of the epidemiologic transition that is observable on the African continent. The unclassified chronic inflammatory rheumatism has been identified as the first cause of arthritis. This high frequency can be explained by the insufficiency of the facilities of investigation; contrary to other countries where this rate in decrease is probably linked to the progress of the diagnostic refinement [5]. Like in Congo, the retroviral infection seems to be the first cause of reactional arthritis $[14,15]$. The rheumatoid arthritis seems less frequent in the black race and unevenly apportioned from one area to another [16,17]. The scarcity of the connective tissue diseases observed in this series seems to reinforce previous researches. [18-20].

The gout represents the second etiologic form of arthritis in our study. The high frequency of this affection in the black patients is henceforth established $[3,6,9,10$,]. The scarceness of renal colic seems to perpetuate the unique clinical particularity in this part of the world [6].

The demographic and semiologic characteristics of the patients suffering from infectious arthritis are comparables to those found with other African studies [21-24]. The risk factors found with our patients superpose themselves to those obtained by other researchers [22,23]. The high susceptibility at joint infections in HIV infected patients has not been found in our series. The same goes with the HIV-tuberculosis co-infection. Prospective researches with rigorous statistic analysis will allow establishing the existence of an eventual link of causality between the frequency of this affection in our countries, the conditions of life of the populations and the increase of the infection by the HIV.

\section{Conclusion}

The chronic inflammatory rheumatisms were the first causal form of arthritis in rheumatologic consultation in Lomé. This study demonstrates the importance of chronic inflammatory rheumatisms despite the weight of the infectious disease in Africa and reflects the scarcity of the connective tissue diseases in black Africa.

\section{REFERENCES}

[1] B. K. Rooney and A. J. Silman, "Epidemiology of the
Rheumatic Diseases," Current Opinion in Rheumatology, Vol. 11, No. 2, 1999, pp. 91-97. doi:10.1097/00002281-199903000-00002

[2] A. Adebajo and P. Davis, "Rheumatic Diseases in African Blacks," Seminars in Arthritis and Rheumatism, Vol. 24, No. 2, 1994, pp. 139-153.

doi:10.1016/S0049-0172(05)80007-1

[3] J. A. Singh, "Racial and Gender Disparities among Patients with Gout," Current Rheumatology Reports, Vol. 15, No. 2, 2013, p. 307. doi:10.1007/s11926-012-0307-x

[4] M. Mijiyawa, K. Etey and M. D. Amédegnato, "Chronic Inflammatory Rheumatic Diseases in Hospital Consultation in LOME (TOGO)," Rhumatologie (Aix-les-Bains) A, Vol. 45, No. 2, 1993, pp. 45-49.

[5] J. C. Daboiko, E. Eti, Y. I. Dollo, B. Ouali, B. Ouattara and N. M. Kouakou, "Inflammatory Rheumatic Diseases at Cocody University Medical Center (Abidjan) from March 1998 to March 2000," Joint Bone Spine, Vol. 71, No. 6, 2004, pp. 598-599.

doi:10.1016/j.jbspin.2004.04.011

[6] M. Mijiyawa, "Gout in Black Africa," La Revue de Médicine Interne, Vol. 15, No. 12, 1994, pp. 797-799.

[7] M. Mijiyawa, O. Oniankitan and M. A. Khan, "Spondyloarthropathies in Sub-Saharan Africa," Current Opinion in Rheumatology, Vol. 12, No. 4, 2000, pp. 281-286. doi:10.1097/00002281-200007000-00008

[8] G. M. Mody, "Rheumatoid Arthritis and Connective Tissue Disorders," Baillière's Clinical Rheumatology, Vol. 9, No. 1, 1995, pp. 31-44. doi:10.1016/S0950-3579(05)80141-4

[9] J. R. Nzenzé, E. Belembaogo, C. Magne, A. S. Sanou, S. Coniquet, J. R. Moussavou-Kombila and J. B. Boguikouma, "Panorama des Arthropathies Inflammatoires à Libreville," Analyse d'une Série de 57 Observations, Médecine d'Afrique Noire, Vol. 48, No. 10, 2001, pp. 399402.

[10] R. Bileckot, G. Koubemba, J. L. Nkoua, R. Bileckot, G. Koubemba and J. L. Nkoua, "Etiology of Oligoarthritis in Equatorial Africa. A Retrospective Study of 80 Cases in Brazzaville, Congo," La Revue de Médecine Interne, Vol. 20, No. 5, 1999, pp. 408-411. doi:10.1016/S0248-8663(99)83092-6

[11] S. I. Wallace, H. Robinson, A. T. Masi, H. Decker, D. J. McCarty and T. F. Yü, "Preliminary Criteria for the Classification of the Acute Arthritis of Primary Gout," Arthritis and Rheumatism, Vol. 20, No. 3, 1977, pp. 895900. doi:10.1002/art.1780200320

[12] B. Amor, M. Dougados and M. Mijiyawa, "Criteria of the Classification of Spondylarthropathies," Revue du Rhumatisme et des Maladies Ostéo-Articulaires, Vol. 57, No. 2, 1990, pp. 85-89.

[13] F. C. Arnett, S. M. Edworthy, D. A. Bloch, D. J. McShane, J. F. Fries, N. S. Cooper, L. A. Healey, S. R. Kaplan, M. H. Liang, H. S. Luthra, et al., "The American Rheumatism Association 1978 Revised Criteria for the Classification of Rheumatoid Arthritis," Arthritis and Rheumatism, Vol. 31, No. 3, 1988, pp. 315-324.

[14] R. Bileckot, A. Mouaya and M. Makuwa, "Prevalence 
and Clinical Presentations in HIV-Positive Patients Seen at a Rheumatology Department in Congo-Brazzaville," Revue du rhumatisme (English Edition), Vol. 65, No. 10, 1998, pp. 549-554.

[15] H. Ntsiba, M. Ngandeu-Singwé, C. Makita-Bagamboula and F. Yala, "Human Immunodeficiency Virus Associated Arthritis in Congo Brazzaville," Médecine et Maladies Infectieuses, Vol. 37, No. 11, 2007, pp. 758-761. doi:10.1016/j.medmal.2006.09.004

[16] A. J. MacGregor, L. K. Riste, J. M. Hazes and A. J. Silman, "Low Prevalence of Rheumatoid Arthritis in BlackCaribbeans Compared with Whites in Inner City Manchester," Annals of Rheumatic Diseases, Vol. 53, No. 5, 1994, pp. 293-297. doi:10.1136/ard.53.5.293

[17] M. Mijiyawa, "Epidemiology and Semiology of Rheumatoid Arthritis in Third World Countries," Revue du Rhumatisme (English Edition), Vol. 62, No. 2, 1995, pp. 121-126.

[18] K. Kombate, B. Saka, O. I. Oniankitan, P. Sodonougbo, A. Mouhari-Toure, K. Tchangai-Walla and P. Pitche, "Systemic Lupus Erythematosus in Lomé, Togo," Médecine Tropicale: Revue du Corps de Santé Colonial, Vol. 68, No. 3, 2008, pp. 283-286.

[19] P. Pitche, K. Amanga, K. Koumouvi, O. Oniankitan, M.
Mijiyawa and K. Tchangaï-Walla, "Dermatomyositis and Polymyositis in Lomé (Togo)," Annales de Dermatologie et de Vénéréologie, Vol. 125, No. 6-7, 1998, pp. 429-430.

[20] P. Pitche, Y. Amanga, K. Koumouvi, O. Oniankitan, M. Mijiyawa and K. Tchangaï-Walla, "Scleroderma in a Hospital Setting in Togo," Médecine Tropicale: Revue du Corps de Santé Colonial, Vol. 58, No. 1, 1998, pp. 65-68.

[21] O. Oniankitan, Y. Bagayogo, E. Fianyo, V. Koffi-Tessio, K. Kakpovi, K. C. Tagbor, P. Houzou and M. Mijiyawa, "Infectious Arthritis in Hospital Patients in Lomé, Togo," Médecine Tropicale: Revue du Corps de Santé Colonial, Vol. 71, No. 1, 2011, pp. 61-62.

[22] H. Ntsiba, E. Makosso, M. Ngandeu-Singwé and F. Yala, "Septic Arthritis in Tropical Environment. 176 Cases Report in Brazzaville," Le Mali Medical, Vol. 21, No. 1, 2006, pp. 49-53.

[23] E. Eti, J. C. Daboiko, S. Debauly, B. Ouali, B. Ouattara and N. Yao, "Pyogenic Arthritis of the Member at Cocody Hospital: A Report of 79 Cases," Rhumatologie (Aix-les-Bains) A, Vol. 52, No. 4, 2000, pp. 18-21.

[24] C. Ben Taarit, S. Turki and H. Ben Maiz, "Infectious Spondylitis. Study of a Series of 151 Cases," Acta Orthopaedica Belgica, Vol. 68, No. 4, 2002, pp. 381-387. 